\title{
Time and Tragedy in Beth Henley's The Jacksonian
}

Verna A. Foster

Loyola University Chicago, vfoster@luc.edu

Follow this and additional works at: https://ecommons.luc.edu/english_facpubs

Part of the English Language and Literature Commons

\section{Recommended Citation}

Foster, Verna A.. Time and Tragedy in Beth Henley's The Jacksonian. Journal of Contemporary Drama in English, 6, 2: 265-279, 2018. Retrieved from Loyola eCommons, English: Faculty Publications and Other Works, http://dx.doi.org/10.1515/jcde-2018-0025

This Article is brought to you for free and open access by the Faculty Publications and Other Works by Department at Loyola eCommons. It has been accepted for inclusion in English: Faculty Publications and Other Works by an authorized administrator of Loyola eCommons. For more information, please contact ecommons@luc.edu. (c) (1) $\Theta \Theta$

This work is licensed under a Creative Commons Attribution-Noncommercial-No Derivative Works 3.0 License. (c) Walter de Gruyter GmbH, Berlin/Boston 2018 


\section{Verna A. Foster* \\ Time and Tragedy in Beth Henley's The Jacksonian}

https://doi.org/10.1515/jcde-2018-0025

Abstract: In The Jacksonian, an autobiographical play set in Mississippi in 1964, Beth Henley filters a tragic action based on the Aristotelian model through the non-linear memory of Rosy, the play's narrator and choric figure, as she tries not to remember that her father has killed her mother. Rosy's father, Bill-a Girardian scapegoat figure contaminated by the racist violence of the community he lives in -is the protagonist of the tragic action. But Henley focuses on its effect on Rosy. A tragic event can occur only in progressive chronological time, but by circling around the murder in her memory, Rosy creates temporal stasis until finally the pressure of denial becomes unbearable and the murder takes place. Tragic inevitability is displaced from the formally tragic action to Rosy's memory of it. A comparison of The Jacksonian with other dramas that incorporate tragic experience within a non-linear time scheme suggests that only in memory plays can tragedy as a genre exist in non-linear time.

Keywords: Tragedy, Non-Linear Time, René Girard, Memory Play

The Jacksonian (2012) is Beth Henley's first play conceived as a tragedy and her first play to use non-linear time (Foster, "Ridiculous" 53). ${ }^{1}$ It is also her first play set in Jackson, Mississippi, where she grew up. The play is a "memory play" (Tennessee Williams's term for The Glass Menagerie) in that it contains autobiographical elements, and the play is "memory" in that its events take place in the mind of the character who is most affected by them, sixteen-year-old Rosy, who serves as the play's narrator, filter, and poetic choric figure (see Williams 131, 145). ${ }^{2}$ While The Jacksonian corresponds in significant ways to Aristotelian trage-

1 An earlier version of this article was presented at the Scholars' Conference at the $36^{\text {th }}$ Annual William Inge Theater Festival in Independence, Kansas, in April 2017. Beth Henley was the Festival honoree.

2 Henley has commented that her memories of growing up in Jackson are the "crux" of the play in terms of both politics and the family (Foster, "Ridiculous" 50).

*Corresponding author: Verna A. Foster, Loyola University of Chicago, E-Mail: vfoster@luc.edu 
dy, the play's non-linear time structure creates an ambiguity that produces the play's peculiar tragic effect and complicates its affect.

The Jacksonian is set in a motel on the outskirts of Jackson from May to December 1964. The play begins just before Christmas on the night when Rosy's father, dentist Bill Perch, murders her mother, Susan, and it repeatedly returns to this night until finally the murder occurs. Interspersed scenes set earlier in time show how the couple got to this point. The non-linear sequence of the scenes reflects Rosy's attempt to put off in her mind for as long as possible what has actually happened. Henley's "Playwright's Note" at the beginning of the published text states, "Rosy's terror and her will quake the landscape of time, space, and memory" (7). ${ }^{3}$ In an interview with me (published in The Southern Quarterly) Henley commented that Rosy is "trying to will that this didn't happen, that her mother isn't murdered if she can just will time" (Foster, "Ridiculous" 54), make some one thing not have happened so that the murder would not take place.

In the background of the family tragedy and seeping into it is the poisonous evil of racism apparent in the casual and accepted racist attitudes expressed in the dialogue, especially that of the motel maid, Eva, and in allusions to lynchings, blowing up black churches and synagogues, and the Ku Klux Klan in a Mississippi on the edge of forced desegregation. Eva observes that she is glad she does not have to go to school with "them," a reference to African Americans that Rosy has no difficulty recognizing as she details that she has "got two in English and three in P.E." (Henley, Jacksonian 21). We learn that an old black man suffering from glaucoma is going to be executed for a murder committed at a local gas station simply because he was the only black person around at the time. In fact, the murder and robbery were committed by Fred, the bartender at the Jacksonian motel, for whom Eva has supplied an alibi in return for his reluctant promise of marriage. Nonetheless, Eva asks Bill, "Don't you think he [the black man] should be lynched?" (18).

For both the historical context of The Jacksonian and the family drama, Henley drew on her own memories and experiences growing up in Jackson in the 1960s from the arrest of the Freedom Riders attempting to desegregate interstate bus terminals in 1961 to the desegregation of her high school in her final semester there in 1970 (Weinert-Kendt). Amidst the violence perpetrated against civil rights activists and by the KKK, Henley remembers in particular the curious detail that her sister's fifth-grade teacher was shot "in hot pants" while involved in a KKK activity (Weinert-Kendt). Henley found the pervasive racism of white society in Mississippi from the governor on down and including even "[p]eople you loved"

3 Quotations from The Jacksonian are taken from the text published by Dramatists Play Service. 
confusing for a child and "a very terrifying and fascinating thing to think about: to be innocent in that time and wonder, when you're young: is this the way of the world?” (Foster, “Ridiculous” 46). Like Rosy, Henley experienced familial as well as political turmoil during the 1960s as her parents separated and divorced. Henley recalls going to her father's hotel room with "a small Christmas tree as a peace offering from her mother" (Weinert-Kendt). Rosy brings such a Christmas tree to her father at the Jacksonian motel. (In performance the tree provides a useful visual marker of the December night of the murder to which the play and Rosy in her mind constantly recur.) The murder of Henley's own mother in 2002 by a burglar provides a further painful autobiographical layer to the action of The Jacksonian.

The political events that make up the play's social context impact the family drama when Bill Perch takes a stand against the racism of his society. He pulls out all of the teeth of a patient who brags about participating in the bombing of a black church. Bill is The Jacksonian's tragic protagonist. He is admirable, even heroic, in standing against the evil of his society, but, as Henley commented in her interview with me, he "has hubris, and he kind of brings himself down"; by his violent mode of action, "he ends up being part of the destruction" (Foster, “Ridiculous” 53). Bill's stance against racial violence causes him to lose his license as a dentist, making him unable to provide for Susan and Rosy and exacerbating the tension between himself and his wife that leads to his murder of her. The murder is linearly the end of the play, but it is not the play's last word. The last scene takes place on a "fine day" (52) in June when Rosy was happy and hoping that her father would go home with her to her mother. This scene suggests the possibility of reconciliation, even of hope, if only in Rosy's mind.

\section{The Jacksonian as Tragedy}

While Henley explicitly conceived of the play as a tragedy, reviewers of productions of The Jacksonian in Los Angeles, New York, and Chicago struggled to define what kind of play it is. Terms such as "black comedy," "who-done-it," "Southern Gothic," "noir," and occasionally "tragic" jostled with comparisons to David Lynch, Flannery O'Connor, and Tennessee Williams in the pages of their reviews. Dmitry Zvonkov, for example, reviewing the New York production, commented on both the play's "dark and light” comic moments and its "tragic, noir-ish, Southern Gothic” quality. Paul Hodgins, however, while recognizing the play's tonal variety, referred unequivocally to The Jacksonian as a "tragedy." He added that the audience at the Geffen Playhouse in Los Angeles reacted to the play "with the same mixture of catharsis and deep appreciation" evoked by Arthur Miller's Death of a 
Salesman (also a memory play), and he compared Bill Perch as a tragic character to Willy Loman (See Zvonkov, Hodgins; also McNulty, Meisel, Brantley, Vincentelli).

The comparison with Death of a Salesman is particularly apposite because of the apparently similar but actually quite different role that memory plays in the two tragedies, both of which in some ways resemble the Aristotelian model. Like Henley, Miller wanted to dramatize how "everything exists together and at the same time" in the mind of his main character (Miller, "Introduction" 136). But there is an important difference. In Death of a Salesman the character whose memories we share is the tragic protagonist, while in The Jacksonian we enter the mind of a suffering observer who is the tragedy's ultimate victim. Miller intersperses episodes from the past that exist only in Willy's memory with scenes that take place over two days in the present. In this sense time in the play is nonlinear. However, the present-day scenes occur in chronological order, thus providing a linear frame for the memories they trigger, which culminate in Willy's guilty remembrance of the night when Biff discovered his father's affair with the Woman in Boston. Memory forces Willy to recognize that he is at least part of the reason why Biff renounced any effort to achieve his father's dream of material success; in the present, still deluded about the value of that dream, Willy kills himself for the insurance money that he falsely assumes will assure Biff's future and thus the meaningfulness of his own life. The guilt Willy finally confronts in his memory plays into the imperfect recognition he experiences at the climax of Death of a Salesman. Whether Willy's failure to understand that he had "the wrong dreams” (Miller, Death 138) undercuts his tragic status or, as Miller suggests, is an intrinsic part of his tragedy (Miller, "Introduction" 147), the interspersion of scenes set in the past with present-day scenes in Death of $a$ Salesman does not significantly disrupt the Aristotelian pre-eminence of plot understood as a logical sequence of events based on cause and effect.

The Jacksonian's tragic structure, by contrast, is fragmented and obscured to a much greater extent by the play's more complex temporal non-linearity. Since in Henley's play the whole of the action takes place in the memory of a character who is not the tragic protagonist, tragic inevitability is displaced from the action itself to Rosy's memory, which circles around and resists but also inexorably pushes forward to the point where Rosy has to remember the murder she wants not to have happened. The fluidity of time in The Jacksonian leaves open the question of what time is, of what is past, and what is present, and what is still possible. The underlying form of the tragedy that is filtered through Rosy's memory nonetheless remains recognizably Aristotelian even as the play foregrounds the tragic experience of the choric observer,

According to Aristotle (writing about tragedy in his Poetics in the fourth century BCE-and still to be reckoned with), a tragedy is a drama that presents a 
horrible action involving the fall from happiness to misery of a reputed individual ("highly renowned and prosperous") of normal or superior virtue, not through wickedness on his part, but through hamartia, or error (Aristotle 76). Tragedy produces in the protagonist some kind of anagnorisis, or recognition, and in the audience the katharsis of pity and fear $(72-73,61)$. The audience pities "unmerited misfortune" and fears for one with whom they can identify- "a man like ourselves" (76). The kind of "tragic incident" most likely to elicit pity and fear "occurs between those who are near and dear to one another"-in other words, within the family (79). Though katharsis is the end or goal of Aristotelian tragedy, Aristotle provides no explanation of the meaning the word has for him in the Poetics. Still a contested term among scholars, katharsis has generally been taken to refer to the emotional effect of tragedy. Tragedy arouses in us and then relieves, moderates, refines, or otherwise beneficially works on our feelings of pity and fear. Most commonly the word katharsis has been translated as "purgation" (a medical metaphor), as in S. H. Butcher's "through pity and fear effecting the proper purgation of these emotions" (Aristotle 61); sometimes as "purification" (a religious metaphor); sometimes the term is connected with intellectual clarification, or enlightenment. ${ }^{4}$ All three of these definitions are relevant to The Jacksonian.

Bill Perch is a contemporary version of Aristotle's tragic protagonist in that he is, or was, a reputed individual in his community, a member of the American Dental Association, as he asserts, and the provider of a home in a wealthy neighborhood for his family. He is sympathetic in his love for his wife and his daughter, for his professional commitment- "I'm known as the Painless Dentist" (Henley, Jacksonian 16), though there may be some hubris in this boast-and for his relative moral decency in a corrupt society. He objects, for example, to the rush to judgment on Louis Wright, the old black man accused of the murder at the gas station, whom he carefully refers to by his name rather than by a racial epithet as Eva does. Perch is also, however, insensitive and prone to violence, and in his despair gets high on dental narcotics such as liquid morphine and chloroform.

Bill makes many mistakes. His first error, an error of insensitivity, was to take their doctor's advice and give permission for Susan to have a hysterectomy while she was under anesthesia for the removal of an ovarian cyst. This event, unsurprisingly, traumatized Susan and precipitated bizarre behavior that led Bill to hit her and to the couple's subsequent estrangement. Hence Bill's sojourn the Jacksonian motel. A second "error in judgment," as Bill calls it, but a "deliberate

4 I have used S.H. Butcher's translation of the Poetics. For an excellent account of the definitions scholars have ascribed to katharsis see Golden, 5-39. 
error" (Henley, Jacksonian 40), is his extraction of all of Phil Boone's teeth as retribution, we later learn, for his patient's acts of racial violence. Bill's motive elicits the audience's sympathy, but in resorting to violence himself, he mimics the behavior he is punishing. On the night of the murder Bill makes a third mistake. He allows his last seductive attempt to get back together with Susan, which appears to be succeeding, to be derailed when he meets Eva at the ice machine and believes her lie that Susan is filing for divorce. Consequently, instead of continuing his attempt at reconciliation, he tells his wife to "go home" (31). Finally, stripped of his professional identity and of any hope of the renewal of his marriage, self-intoxicated, and with no "deus ex machina" (44) in sight, ${ }^{5}$ Bill indulges in peculiar intimate, compensatory behavior with Eva, putting his fingers into her mouth and then knocking her out with chloroform. Susan, returning to the motel, finds him in this compromising situation. She taunts him with his inability to provide for her and with his own family's racist heritage. Pushed to his limit, Bill snaps. In a paroxysm of violence, he dopes, strangles, and batters Susan to death, becoming, as Henley says, part of the destruction he abhors.

Speaking as both grieving daughter and choric commentator, Rosy insists that there were "no reasons" for the things her parents did that "they should not have done." Despite the clear personal and familial motivation that Henley provides for Bill and Susan's actions, Rosy blames instead "the swamp you're living on that pulls you under. / Under weeds, wet grass, mud. Lifetimes of rot and blood, lynched blood, buried in Mississippi soil" (Henley, Jacksonian 34). Later, realizing she cannot hold back the memory of the murder much longer, she says, "The swamp is rising to cover us all," followed immediately by the line "Another fire bomb in Meridian" (41). Rosy's commentary reinforces the causal connection between societal and familial violence and evil in the play.

The social evil of racism in The Jacksonian corresponds to the external force, often conceived as fate, in Greek tragedy that cooperates with what the protagonist himself does to bring about his own downfall. Rita Felski succinctly describes this perennial condition of tragedy: "what distinguishes tragedy is an uncanny unraveling of the distinction between agency and fate, internal volition and the pressure of external circumstance" (Felski, Introduction 11). The societal evil of racism that puts pressure on Bill's behavior is present in his own family; his father, we eventually learn, belonged to the Ku Klux Klan. At the end of the play Susan yells at Bill that he is "[f]ull of hate," like his "daddy," and that he, too, should "Join the KKK!" (Henley, Jacksonian 49). She throws a sheet over his head.

5 Bill's comment that he had "been hoping for some deus ex machina" (44) points to the influence of Greek tragedy on The Jacksonian. 
Bill soaks this symbol of racist evil in chloroform and puts it over his wife's face prior to murdering her. Bill's heritage of racial violence is like the family curse in Greek tragedy (in the Oresteia of Aeschylus, for example). Bill's heritage, or curse, passed down through generations, manifests in his own act of violence, though its object, the wife he still loves, is a substitute for the racist community that he desires to punish. Susan is a relatively innocent though still tainted member of that community. In effect, she is a scapegoat. Dying, she seems to recognize the need for ritual purification: "Let the terror-the terror. . . . Purify our blood" (4950).

Imagery of blood suffuses The Jacksonian from Bill's first appearance at the ice machine with "blood on his hands and shirt" at the beginning of the play to the repetition of the scene at the end (Henley, Jacksonian 9, 50). Blood in The Jacksonian is multi-valenced. It is at once the literal product of physical violence, a metaphor for the material or spiritual substance of an individual or of a community, and a symbol for sacrificial purification. As a dentist, Bill explains to Eva, he is accustomed to blood "on my hands, on my smock" because a "lot of blood comes from the mouth" (44), so he was able to remain clinically detached when blood from Phil Boone's tortured mouth poured over him. The image of spurting blood is prefigured in Fred's explanation to Rosy of why he had to give up his sword-swallowing act: after he lacerated some blood vessels in his trachea, blood "shot" out of his mouth "in a gush. A ruby fountain." Demonstrating his act on a small scale, Fred swallows and then draws from his mouth the blood-stained blade of a table knife. He tells Rosy he did it for her. Appalled, Rosy orders him, “Don't bleed for me. Don't ever" (29). The curiously ambiguous wording suggests that Fred's act has been not only a performance but some kind of strange sacrificial rite, an implication that makes little sense here but that does foreshadow the blood sacrifice with which the play reaches its climax. Susan's head bleeds when Bill batters her against the wall.

Earlier Susan had insisted that if ever she took her own life, it would be in a way that did not involve any blood because "Blood is private" (Henley, Jacksonian 26). The corollary is that spilt blood becomes public. Fred explains to Susan the history of executions in Mississippi. The people in Sunflower County, he says, were not happy when the "portable electric chair" was replaced by the gas chamber constructed at Parchman Penitentiary because they "did not want all the evil blood in the state spilled on their land alone" $(38,39) .{ }^{6}$ The "evil” blood, like

6 Fred's seemingly bizarre disquisition on executions in Mississippi from hanging to the use of the "portable electric chair" (38)-invented in Mississippi-to the gas chamber at Parchman Penitentiary and the local people's objection to it is historically accurate. See Cabana. 
the "lynched blood, buried in Mississippi soil" (34) that Rosy refers to, is the blood of black people (murdered judicially or extra-judicially). Their spilt blood metaphorically poisons both the climate-just after Fred's impromptu history lesson, Susan says, “There's something in the humidity that makes me perspire drops of blood" (39)-and the lives of even the innocent such as Rosy. ${ }^{7}$ It seems that only blood can purify blood and create the possibility of a better social order.

In Violence and the Sacred René Girard observes that blood can "stain or cleanse, contaminate or purify" (37). This duality of blood is apparent in The Jacksonian. In fact, the action of the play corresponds not only to Aristotelian tragedy but also in some respects to the work of sacrificial violence that Girard believes underlies Aristotle's conception of tragedy and in particular katharsis (290-291). According to Girard, the purpose of sacrificial violence is to protect the community from a cycle of reciprocal violence (4). Since violence provokes further violence, only by substituting a surrogate victim for the perpetrator of violence (or through legal punishment if it is available [22]) can a community "deflect" reciprocal violence, "restore harmony," and "reinforce the social fabric" $(4,8)$. While Henley does not present any such favorable outcome of the violence perpetrated in The Jacksonian, the play's conclusion gestures towards the possibility of something better arising out of the horror we have witnessed.

Girard argues that almost all violence is inherently sacrificial (1). Vengeance, sacrifice, and legal punishment, he asserts, share a "fundamental identity" (25). In Jackson, Mississippi circa 1964 the legal punishment of white crimes against black people is clearly unavailable. So Bill takes it upon himself to punish Phil Boone for his acts of racist violence. The "fundamental identity" of the vengeance Bill enacts on Boone and the legal punishment that fails to operate is reinforced by the curious similarity between Bill's dentist's chair, the site of Boone's punishment, and the "portable electric chair" that Fred describes to Susan. In enacting violence against Boone, however, Bill is himself “contaminated” by his victim's violence (see Girard 27); he goes on to commit further opportunistic and irrational acts of violence against Eva, who embodies the racism of her society, and Susan, who is also a member of the racist community but retains some elements of decency-she is at least opposed to the Ku Klux Klan. Susan becomes an accidental sacrificial scapegoat, both tainted and innocent, simply because she is in the wrong place at the wrong time, as Rosy sees it.

As the Jacksonian's tragic protagonist, Bill, too, is a scapegoat. Girard argues that "the qualities that make a 'good' [Aristotelian] tragic hero are precisely those

7 Rosy's acne, exaggerated as large red blotches in performance (see Adamek, Meisel), may symbolize how the poison has seeped even into an otherwise innocent young girl. 
required of the sacrificial victim": both hero and victim should be familiar and unfamiliar, neither wholly good nor wholly bad, capable of arousing sympathy in members of the audience or community but also possessing a "weakness" that allows the observers “to tolerate the hero's downfall and death" (Girard 291). Like Oedipus, Bill is both a member of his community and an outsider (alienated from it in Bill's case); his character and behavior are morally mixed; he is sympathetic but deserving of punishment. Bill takes upon himself the violence of his community by enacting it, but his murder of Susan replicates the evil he stands against in the worst possible way. His judicial punishment will put an end to the particular cycle of violence in which he has participated, but it will not restore to his community a "harmony" that did not exist in the first place. Bill's tragedy, however, creates katharsis for the theatre audience.

After the murder takes place, Henley returns us to the "beginning scene of the play" as Bill, covered in blood, stands by the motel's ice machine, and ice, again, portentously "crashes" out of it (Henley, Jacksonian 50). At this moment he perhaps has an anagnorisis, or recognition, of what he has done. He is willing at least to accept responsibility for his action since, Rosy tells us, he "called the authorities" and "is in jail/ waiting on the gas chamber" (51)-a macabrely ironic punishment for a dentist who gets high on his own nitrous oxide. By murdering his wife, Bill purges violence with violence in an act that can be seen as a purification, or necessary cleansing, of social evil, though at a terrible cost. Bill destroys his wife, himself, and his family. For the audience the explosive murder to which the play has been building provides katharsis in the sense of emotional release from the "purgatory," Henley's word, "that was Jackson circa 1964" (7). But there is also enlightenment. In its refusal to turn away from "the horror of what human nature is capable of" and its depiction of how evil "begets evil," in Henley's words (Foster, “Ridiculous" 54), The Jacksonian to an extent frees its audience from the horror by making us face it. The last scene of the play, in which Bill and Rosy have a "fine day" (Henley, Jacksonian 52), even though it is in the past, Henley suggests, reinforces the possibility of something "better" (Foster, "Ridiculous" 54) coming out of the evil we have witnessed.

\section{Non-Linear Time in The Jacksonian}

The temporal ambiguity of The Jacksonian complicates the tragedy, disrupting any clear sense of cause and effect and conflating the despair of the inevitable with hope for the impossible. Time in the play is complex and multi-layered. The motel itself, Henley tells us, "exists as a haunting memory" (Henley, Jacksonian 7). The non-linearity of the scenes leading to Bill's murder of Susan requires the 
audience to peer through the murk to piece together the causes of their disintegrating marriage and also to uncover the basis-which turns out to be the earlier murder at the gas station-of Eva's fraught relationship with Fred. Rosy's addresses to the audience are outside even this non-linear time sequence, as if on a different plane, as is indicated when she breaks frame by "step[ping] through space and speak[ing] to the audience" (15) or when she "leaves the motel room and steps through time into the bar" (27). In her mind Rosy pushes back against the play's inevitable climax, confusing past, present, and future. At the beginning of the play she mixes tenses: "There's been an accident there's going to be I need to stop an accident at the motel” (9); at the beginning the murder has and has not taken place.

But time passes inexorably, as The Jacksonian's numerous references to time constantly remind the audience, and as Rosy is all too aware. Both Rosy and Bill try to fool themselves about time. Rosy pretends that her parents' separation is "a temporary measure" (Henley, Jacksonian 15), and Bill describes his current situation-living at the Jacksonian motel, no longer having a job-as "a lull, a lull is circular, it's round" (12). Even apparently casual references to time such as Bill's compliment to Fred on his "Good timing" (15) as a bartender or Bill's complaint about Susan's inability to grasp "the importance of time" build to something ominous, as Bill adds, "She doesn't see that things can only happen in time" (20). Later in the play Eva says, "I hope I live a long time. It's the only time I have not to be in hell" (42), unaware that she is already living in hell.

Rosy's attempt to hold back time eventually gives way to her realization that stopping time is impossible and letting go might even be a relief: "I don't let time go but it goes. / It pulls forward to the night of murder. / And I am released" (Henley, Jacksonian 41). In her monologue after the murder has occurred, Rosy no longer mixes past and future tenses as she does at the beginning of the play. Instead she speaks in the past tense to explain what has happened: "Fred ran off," "Eva lost her mind to the chloroform," and "Mama died alone in the room" (51). The conflict between what has happened and Rosy's refusal to remember has finally disappeared. Her monologue concludes with a series of desperate conditional sentences showing that Rosy has accepted-though reluctantly and still wishing that things could be otherwise-her father's murder of her mother: "If tonight did not happen I expect we could work things out. We'd make an effort. A sincere effort. And things would be changed. There still would be time" (51).

Rosy's acceptance of the tragedy is as much the play's moment of anagnorisis as is Bill's acceptance of responsibility for the murder of his wife. Her acceptance leads to the possibility of retaining a happier memory of the "fine day" (Henley, Jacksonian 52) in June that she shared with her father. The Jacksonian ends with this day, completing the katharsis (in the sense of purgation, purification, enlight- 
enment) effected by the tragedy. The final mood is at once calming and painful as the temporal dislocation of this scene underscores the ironic discrepancy between what is and what might have been and what in Rosy's mind might still be. The scene, and the play, ends with Bill saying he will come home "Maybe today." “Today," Rosy repeats (53).

In an earlier typescript of The Jacksonian (dated 2012), which I was privileged to read in preparation for my interview with Henley, Rosy's opening address to the audience begins with the line "The time is-what time is . . I feel the skin of time but don't know where it touches" (1). This resonant image expresses Rosy's sensuous but confused experience of time and suggests further that the play may be seen, not only as a tragedy about racial and familial violence in 1960s America, but also as a meditation on the way we experience time and the uncertainty of memory in making sense of our experiences. Rosy's intense desire that her father should not have murdered her mother is responsible for the non-linear fluidity of time in The Jacksonian. That we enter the play through Rosy's subjectivity may call into question whether the tragic action that we witness has actually occurred. In the earlier typescript, as she reflects on the murder at the end of the play, Rosy mixes tenses as she does at the beginning and imagines that perhaps the murder did not really happen: "If it turns out this is not real anymore. And things are before, things are after-things became" (77). In the published text Henley pares down Rosy's references to time and erases these lines in particular, making it definitive that Rosy's father has murdered her mother. Any remaining confusion exists only in Rosy's mind. In her interview with me Henley explained that "the whole of the play takes place in a flash of Rosy trying not to realize what's happened-that her mother's dead" (Foster, “Ridiculous” 54). ${ }^{8}$ All of Rosy's impressions and memories, her hopes and her fears, exist in her mind simultaneously. They do not succeed one another-though on the stage they must. They are not alternatives to one another. Rather all are equally present for Rosy-the December night of the murder, the "fine day" in June, as well as another, long-ago day at the zoo.

In the play's final scene-Rosy's memory of a "fine day"-Rosy remembers another, earlier day when she was "real little" that she spent with her parents at the zoo. She remembers that her hat fell into the rhinoceros pit and Bill jumped in to retrieve it for her: "People were cheering you because you had risked your life to save my hat" (Henley, Jacksonian 52). But since Bill does not remember this (admittedly improbable) incident, the possibility exists that Bill jumped into a pit

8 Miller similarly comments that he would have liked the whole of Death of a Salesman to occur in "a single flash of light” (Miller, Introduction 136). 
with a rhinoceros to retrieve Rosy's hat only in Rosy's imagination. This ambiguity then reflects back on all the other memories in the play to suggest, not that Rosy's testimony about what has happened is unreliable, but rather to underscore how imagination can imbue memory with hope even in the face of the grimmest despair and create the possibility, however tenuous, of something "better" arising out of tragedy.

\section{Tragic Experience and Non-Linear Time}

While common enough today, explicit disruptions of linear time such as those created by Rosy's resistance to fact are a relatively recent phenomenon in the history of drama. Dramatists began to experiment with non-linear time in the early-twentieth century for a variety of reasons, ranging from a post-Freudian, post-Strindbergian concern with dreams and the inner consciousness to competition with the new medium of film's ability to present time in non-linear ways, including running it backwards; from a desire to construct alternate realities in response to the horrifying suffering and numbers of deaths incurred in World War One to post-Einsteinian views of the relativity of time itself. The filtering of tragic actions through non-linear time is one of many ways in which modern drama has loosened tragic experience from its traditional generic contours, particularly from the Aristotelian pre-eminence of plot understood as the logical sequence of events, and disrupted tragedy's cathartic affect. Plays as various as J. B. Priestley's Time and the Conways (1937), Arthur Miller's Death of a Salesman (1949), Samuel Beckett's Waiting for Godot (1954), Tom Stoppard's Arcadia (1993), SuzanLori Parks's The America Play (1993), and Sebastian Barry's Tales of Ballycumber (2009), as well as Henley's The Jacksonian, address implicitly tragic motifs but dislocate events from their chronological sequence or blur different time periods or present time itself as indeterminate. Unlike The Jacksonian and Death of a Salesman (significantly both memory plays), however, most such dramas are not in the end tragedies.

In Arcadia, which takes place at Sidley Park, a great country house, Stoppard alternates scenes set in the early-nineteenth century with scenes set in the present and finally blends them. The action in the past concludes with the imminent death of the incandescent young mathematical genius, Lady Thomasina. Since the audience has learned in an earlier, present-day scene that Thomasina died in a fire, the play's final moments, in which Septimus, Thomasina's tutor, lights her bedtime candle and the two waltz romantically together, are almost unbearably poignant. Or they would be were it not that simultaneously, in the present, Hannah and Gus are dancing together, "rather awkwardly" (Stoppard 97), and 
Gus (a strange, silent boy, descended from Thomasina's brother) has just given Hannah, who is writing a history of the garden, the evidence she needs to prove that the hermit of Sidley Park was in fact Septimus. Devastated by Thomasina's death, Septimus lived out the rest of his life and perhaps went mad trying to prove her precocious anticipation of the theory of chaos. In the present day Thomasina's insights have been justified. The structural patterning of the play situates its painful emotional affect within Stoppard's celebratory intellectual framework. As Septimus tells Thomasina, "We shed as we pick up, like travellers who must carry everything in their arms, and what we let fall will be picked up by those behind" (38).

In fact, for the most part, plays that adopt non-linear time schemes are not tragedies-not only because non-linear temporal structures generally disrupt cause and effect relationships but also because they allow for more and even contradictory possibilities. In The America Play Parks adopts temporal sleight-of hand to recuperate tragic history. In this play the Foundling Father, a black lookalike for Abraham Lincoln, conflates his life with Lincoln's, making a living from people who pay to shoot "Lincoln" at "the Great Hole of History" (Parks, "America" 159), an amusement park that paradoxically represents both the "whole" of history and the "hole" that is the tragic absence of African-American experience from recorded history. In the play's second act Lucy, the Foundling Father's wife, and Brazil, their son, dig up from the great hole various artifacts associated with Lincoln. Among the artifacts is the Foundling Father, now a "Wonder: One of thuh greats Hisself!" (199), who finally takes his place in the Hall of Wonders curated by Brazil. Parks has written of her plays, "I'm re-membering and staging historical events which, through their happening on stage, are ripe for inclusion in the canon of history" ("Possession” 5). Through Parks's exuberant staging of the Foundling Father's performance as Lincoln and Lucy and Brazil's archeological activity in digging him up, The America Play, symbolically at least, recreates the past and restores African Americans to their own history.

Often modern dramas that incorporate the most painful forms of tragic experience are actually tragicomedies, plays in which various kinds of comedy both undercut and reinforce what is tragic. ${ }^{9}$ A classic example of modern tragicomedy, Waiting for Godot, is so designated by Beckett himself on the title page. In Waiting for Godot time is indeterminate, repetitive, and static. No one knows what time it is or how much time passes. In such a temporal environment neither tragic nor comic actions can be worked out to fulfillment. The result is that what is tragic

9 For a discussion of tragicomedy see Foster, The Name and Nature of Tragicomedy, especially pp. 166-176 on Waiting for Godot. 
becomes comic and what is comic participates in the tragic. If, as Estragon says, "Nothing happens" (Beckett 43), then tragedy cannot happen.

Indeed, if "things can only happen in time" (Henley, Jacksonian 20), as Bill Perch observes in The Jacksonian, then tragedy can occur only in progressive chronological time. By refusing to know where (or when) she is in time and by denying time's forward movement, Rosy creates subjective temporal stasis as her memory circles around and attempts to void her father's tragic murder of her mother. But in the end Rosy has to allow time to move forward, so the tragedy occurs. In effect, Henley pits what Manfred Pfister in The Theory and Analysis of Drama calls "objective chronometry" against "the subjective perception of time," and "progress" (the murder does occur) against "stasis" (Rosy's refusal to remember) (see Pfister 288-90). The tension these conflicting structural imperatives produce gives The Jacksonian its distinctive affect while allowing the play to retain its tragic contours.

Perhaps, we might conclude, only in memory plays, like Death of a Salesman and The Jacksonian, can tragedy exist in non-linear time, or in the "flash" that for both Miller and Henley the non-linear structure of their plays is meant to represent (see above, note 8; Foster, "Ridiculous" 54). What Rosy remembers is a tragic action of Aristotelian proportions, an individual destroying himself in an attempt to purify his community, but it is also an action that constitutes Rosy herself as tragic victim. Only by disrupting time with her own alternative version of the past -her father did not kill her mother-can she control what has happened. But that narrative proves impossible to sustain. In her mind Rosy can no longer resist the fact of the murder at the Jacksonian motel. In offering her own memory of the day at the zoo in the play's last scene, however, Rosy creates an alternative version of the past that is less susceptible to contradiction, a memory that allows for healing and offers the hope of reconciliation. And this moment too exists at the same time as all of the other moments in the play. It is a moment of stasis, but because it comes at the end of the play, it looks like progress to the audience.

\section{Works Cited}

Adamek, Pauline. “The Jacksonian at the Geffen-Beth Henley’s Eerie and Murderous Drama." ArtsBeatLA, 8 Mar. 2012, www.artsbeatla.com/2012/03/the-jacksonian-geffen/. Accessed 14 May 2012.

Aristotle. Aristotle's Poetics. Translated by S. H. Butcher, Hill and Wang, 1961.

Beckett, Samuel. Waiting for Godot. Grove Press, 1954.

Brantley, Ben. "The Sweet Smell of Decay Pervades a Whodunit." The New York Times, 15 Dec. 2015, www.nytimes.com/2013/11/08/theater/reviews/the-jacksonian-stars-ed-harris-atthe-acorn-theater.html. Accessed 30 Jan. 2017. 
Cabana, Donald A. “The History of Capital Punishment in Mississippi: An Overview.” Mississippi History Now. An Online Publication of the Mississippi Historical Society, Oct. 2004, www. mshistorynow.mdah.ms.gov/articles/84/history-of-capital-punishment-in-mississippi-anoverview. Accessed 22 July 2017.

Felski, Rita. Introduction. Rethinking Tragedy, edited by Rita Felski, Johns Hopkins UP, 2008, pp. 1-25.

Foster, Verna A. “Ridiculous Fraud and The Jacksonian - Beth Henley’s New Plays About the South: An Interview.” The Southern Quarterly, vol. 50, no. 1, Fall 2012, pp. 43-57.

Foster, Verna A. The Name and Nature of Tragicomedy. Ashgate, 2004.

Girard, René. Violence and the Sacred. Translated by Patrick Gregory, Johns Hopkins UP, 1977. Golden, Leon. Aristotle on Tragic and Comic Mimesis. Scholars Press, 1992.

Henley, Beth. The Jacksonian. Dramatists Play Service, Inc., 2014.

Henley, Beth. "The Jacksonian.” Feb. 29, 2012. TS.

Hodgins, Paul. “Ed Harris, Bill Pullman Shine in Henley’s Bloody, Brilliant 'The Jacksonian'.” Orange County Register, 17 Feb. 2012, www.ocregister.com/articles/henley-340664-jacksonian-bill.html. Accessed 14 May 2012.

McNulty, Charles. “Theater Review: 'The Jacksonian’ at the Geffen.” Los Angeles Times, 17 Feb. 2012, latimesblogs.latimes.com/culturemonster/2012/02/theater-review. Accessed 14 May 2012.

Meisel, Myron. "The Jacksonian: Theater Review.” The Hollywood Reporter, 25 Feb. 2012, www. hollywoodreporter.com/review/jacksonian-theater-review. Accessed 14 May 2012.

Miller, Arthur. Death of a Salesman. Penguin Books, 1976.

Miller, Arthur. "Introduction to the Collected Plays." Reprinted in The Theater Essays of Arthur Miller, edited by Robert A. Martin, Viking Press, 1978, pp. 113-170.

Parks, Suzan-Lori. “Possession.” The America Play and Other Works. Theatre Communications Group, 1995, pp. 3-5.

Parks, Suzan-Lori. "The America Play.” The America Play and Other Works. Theatre Communications Group, 1995.

Pfister, Manfred. The Theory and Analysis of Drama. Translated by John Halliday, Cambridge UP, 1991.

Stoppard, Tom. Arcadia. Faber and Faber, 1993.

Vincentelli, Elizabeth. “Life Heads South in ‘The Jacksonian’.” New York Post, 7 Nov. 2013, nypost.com/2013/11/07/life-heads-south-in-the-jacksonian/. Accessed 30 Jan. 2017.

Weinert-Kendt, Rob. "Southern Without the Comfort." The New York Times, 11 Jan. 2012, www. nytimes.com/2012/01/15/theater/in-the-jacksonian-beth-henley. Accessed 14 May 2012.

Williams, Tennessee. The Glass Menagerie. The Theatre of Tennessee Williams, vol. 1. New Directions, 1971.

Zvonkov, Dmitry. "Off-Broadway Theater Review: The Jacksonian (Acorn Theatre)." Stage and Cinema, 7 Nov. 2013, www.stageandcinema.com/2013/11/07/the-jacksonian-acorn-theatre/. Accessed 30 Jan. 2017. 